International Journal of Managing Value and Supply Chains (IJMVSC) Vol. 3, No. 1, March 2012

\title{
GREEN SUPPLY CHAIN MANAGEMENT: A REVIEW AND RESEARCH DIRECTION
}

\author{
Noor Aslinda Abu Seman ${ }^{1}$, Norhayati Zakuan ${ }^{1}$, Ahmad Jusoh $^{1}$ and Mohd Shoki \\ Md Arif \\ ${ }^{1}$ Faculty of Management and Human Resource Development, Universiti Teknologi \\ Malaysia, 81310, UTM Skudai Malaysia \\ norhayatimz@utm.my \\ Muhamad Zameri Mat Saman ${ }^{2}$ \\ ${ }^{2}$ Faculty of Mechanical, Universiti Teknologi Malaysia, 81310, UTM Skudai Malaysia
}

\begin{abstract}
Green Supply Chain Management (GSCM) has appeared as an environmental innovation which integrates environmental concerns into supply chain management. GSCM has gained popularity with both academic and practitioners. The purpose of the paper is to briefly review the recent literatures of the GSCM and also determine the new direction area of this emerging field. A detailed review is used to sort out the literature and develop the research direction of the study. The review is focused on development of GSCM in a developed and developing countries including all those researchers which is relevant to environmental and social sustainability towards operation management and the supply chain. It shows that lack researches to examine the adoption and implementation of GSCM practices especially in developing countries such as Malaysia. Thus, the authors bring forward a proposed research direction on GSCM adoption and implementation in Malaysia's manufacturing industries.
\end{abstract}

\section{KEYWORDS}

Supply Chain Management, Green Supply Chain Management, Environmental Management, ISO 14001 Certified Manufacturing Firms

\section{INTRODUCTION}

The economic growth increases the level of energy and material consumption, which contribute to the environmental issues and resource depletion problems. It has become increasingly significant for organizations facing competitive, regulatory, and community pressures to balance economic and environmental performance [1]. Nowadays, most organizations are starting to go green in their business as concern to environmental sustainability. They have realized the greater benefit of the green technology adoption in business operation, which also affected suppliers and customers. Environmental issues under legislation and directives from customer especially in the US, the European Union (EU), and Japan become an important concern for manufacturers [2]. As a result, Green Supply Chain Management (GSCM) emerges as a new systematic environmental approach in supply chain management and has been increasingly accepted and practices by forward-thinking organization [3].

The current changing in environmental requirements that influenced manufacturing activities had increased attention in developing environmental management (EM) strategies for the supply chain [4]. Thus, the concept of GSCM arises as a new systematic approach and becoming an important factor for business activities today. Zhu et al. [5] also claimed GSCM can be regarded as an environmental innovation. By integrating the 'green concept to the supply chain' concept, it has created a new research agenda where the supply chain will have a direct relation to the

DOI: $10.5121 /$ ijmvsc. 2012.3101 
environment [6]. Thus, it becomes interesting issue because the past literatures showed these two paradigms were related each other [7].

The purpose of this paper is to discuss an overview of the development of GSCM literature in a developed countries and developing countries. This study also is performed to determine the new research area of issues related GSCM's implementation. This paper will then provide a thorough review from previous studies. At the end, this paper will propose the research direction framework for the study.

\section{LITERATURE REVIEW}

\subsection{Green Supply Chain Management}

It is important to integrate environmental management practices into the whole supply chain management in order to achieve a greener supply chain and maintain competitive advantage [8] and also increase business profit and market share objectives. Various definition of GSCM exist in the literature. Accordingly, Zhu and Sarkis [3] defines GSCM as has ranged from green purchasing to integrated supply chains starting from supplier, to manufacturer, to customer and reverse logistics, which is "closing the loop". According to Srivastava [7], GSCM can be defined as "integrating environmental thinking into supply chain management, including product design, material sourcing and selection, manufacturing process, delivery of the final product to the consumers as well as end-of-life management of the product after its useful life".

The quality revolution of the 1980s and the supply chain revolution of the 1990s extend the green supply chain literature with the beginning of corporate environmental management, environmentally conscious manufacturing strategy, and supply chain management literature [9]. It has become clear that the best practices call for integration of environmental management with ongoing operations [7]. Green supply-chain management (GSCM) is gaining increasing interest among researchers and practitioners of operations and supply chain management. The past literature also shows that most researchers have studied the GSCM adoption and implementation on developed countries such as Japan, Germany, Portuguese, UK and Taiwan and so on. Still limited studies have examined the GSCM practices in developing countries.

\subsection{Green Supply Chain Management in Developed Countries}

Developed countries can be described as a high level development of countries based on certain characteristics. These characteristics consist of economic, industrialization and Human Development Index (HDI). The economic characteristic is income per capita. Countries with high income or gross domestic product per capita can be categorized as developed countries. Then, developed countries according to industrialization characteristic are the tertiary and quaternary sectors of industry. Another recently measure, the Human Development Index (HDI) integrate an economic measure, country income, with indices for expectancy and education. Developed countries can be defined from this characteristic as those have a higher HDI rating. Thus, the developed countries are believed to deal with lots of environmental issues and depletion problems due to their increasing economic development. Most researchers conducted their study in developed countries to examine the integration of environmental concept and supply chain management.

One study from Germany conducted by Large and Thomsen [10] identified five potential drivers of green supply chain management performance: green supply management capabilities, the strategic level of purchasing department, the level of environmental commitment, the degree of green supplier assessment, and the degree of green collaboration with suppliers. Azevedo et al. [11] examined the links between green practices of supply chain management and supply chain performance in the context of the Portuguese automotive supply chain. This study obtained the conceptual model from data analysis that provide evidence as to which green 
practices have positive effects on quality, customer satisfaction and efficiency also negative effects on supply chain performance.

In the study of Chiou et al. [12] in Taiwan has explored the correlation between greening the supplier and green innovation in Taiwan industry by using Structural Equation Modeling. They concluded that greening the supplier through green innovation leads to significant benefits to the environmental performance and competitive advantage of the firm. Through a study in Italy by Cagno et al. [13] examined the GSCP adopted by Third Party Logistics (3PLs) service providers such as specific practices implemented and level of adoption of each practices and also examined the relationship of various GSCP implementation and company performance. In this study, the work offers a depth understanding of potential effects of GSCP on company performance.

The study from Japan conducted by Arimura et al. [14] determined the influence of ISO 14001 certification on the green supply chain management (GSCM) by using Japanese facility leveldata. The study proved that ISO 14001 and also voluntary EMS government program are significantly influence GSCM practices. These programs highly perhaps the facilities will evaluate their suppliers' environmental performance and ask suppliers to undertake specific environmental practices. Another study from Japan by Zhu et al. [5] sought to introduce environmental, green supply chain management experiences of large Japanese manufactures. This work shows that the large companies can green their supply chain by creating win-win relationships with their partners, and hence realize the sustainable growth for the entire supply chains. Besides, it also indicates that suitable regulations and policies set by government can help GSCM circulation from larger leading companies to smaller companies.

$\mathrm{Hsu}$ and $\mathrm{Hu}[15]$ investigated the consistency approaches by factor analysis that determines the adoption and implementation of GSCM in Taiwanese electronic industry. The fuzzy analytic hierarchy process method was applied to prioritize the relative importance of four dimensions and 20 approaches among nine firms in electronic industry. Meanwhile, Shang et al. [16] explored key green supply chain management (GSCM) capability dimensions and firm performance based on electronics-related manufacturing firms in Taiwan. On the basis of a factor analysis, six green supply chain management dimensions were identified: green manufacturing and packaging, environmental participation, green marketing, green suppliers, green stock, and green eco-design.

Holt and Ghobadian [17] investigated the level and nature of greening the supply chain in the UK manufacturing sector. In this study, the work explores the driving forces behind environmental, the specific management practices that result, and the relationship between them. The study by Nawrocka et al. [18] in Sweden, has concentrated on the role of ISO 14001 in environmental supply management practices in Swedish companies. The study described the existing and potential role of ISO 14001 for three key operational tasks of environmental supply chain management: to communicate the requirements to the supplier, to motivate and enable the supplier, and to verify that the supplier follows the requirements.

Moreover, the study from South Korea carried out by Lee [19] has identified the drivers of participation in green supply chain initiatives by considering small and medium-sized suppliers and their most important stakeholders, including buyers and the government. Raymond et al. [20] examined the relationship between supply chains and environmental performance of SMEs in Canada. This study proved that time and financial resources to deal with solid waste and energy issues are the most limiting factors.

In addition, Chen [21] looked into the relationship between green innovation and green image of companies in Taiwan. The study proposed a new concept of green core competence. Chien and Shih [22] examined the adoption of GSCM practices among the electrical and electronic industry in Taiwan. The relationship between green supply chain management practices and environmental performance, as well as financial performance has been studied. 
One study from Australia, conducted by Simpson et al. [23] explored the moderating impact of relationship conditions existing between a customer and its suppliers and effectiveness of the customer's environmental performance requirements (otherwise known as "green-supply"). Practically no research exists on the actual effectiveness of green supply requirements when placed in context with the realities of inter-organizational dynamics.

\subsection{Green Supply Chain Management in Developing Countries}

Green supply chain practice commonly is believed to represent the environmentally-friendly image of products, process, systems and technologies, and how the business is conducted [24]. Nonetheless, as stressed by Anbumozhi and Kanda [25] most companies especially in developing countries adopted the green solutions into their business more tries to reduce the negative environmental effects rather than adopting a proactive approach to reduce the sources of waste or pollution. Then, these adopted green solutions continue to be the traditional command-and control or "end-of-the-pipe" solutions [25]. Therefore, there is needed to put more interest in studying the adoption and implementation of GSCM in developing countries due to the "end-of-the-pipe" approach. Little research attention has been devoted to the concern of GSCM in developing countries especially in Asian Regions. The GSCM concept is a relatively new concept in South East Asian Region and probably only a few companies are actually able to implement it [26]. However, as claimed by Rao [26] in his study on green supply chain in South East Asian Region (Philippines, Indonesia, Malaysia, Thailand, and Singapore) found that environmental supply chain practices had started to take place. Thus, the findings from those researches in Asian Region can be useful for manufacturing in developing countries in order to develop the appropriate GSCM practices and help to reduce the environmental problems.

Recent literature showed that most researchers starting investigate on GSCM in East Asian Region especially China as developing country. The issues related to GSCM have become even more critical in China. Although China gains more opportunities as a major manufacturing country, they also deal with huge environmental problems with this opportunity [26]. Zhu et al. [27] investigated whether different Chinese manufacturer clusters varying in their extent of implementing GSCM exist from the ecological modernization perspective. The study also examined whether Chinese manufacturers' awareness of local and international environmental ESPR-oriented (enhancing energy savings and pollution reduction) compliance is related to GSCM implementation and also either a mediating effect of regulatory pressure plays a major role. Then, study found that the varying pace of Chinese manufacturers to ecological modernize with GSCM practices and the significance of regulatory pressure to distribute the practices adoption by Chinese manufacturing industry.

The study by Liu et al. [28] in China has analyzed the relationship between green supply chain management level (LGSCM) and the classified determinant factors. The study confirmed that a company's environmental management capacities will be strongly enhanced by frequent internal training of employees to increase its involvement in GSCM practices. Another research from China, studied by Yan Li [29], examined the adoption levels of GSCM practices in China and explored the performance measurement for GSCM. The findings demonstrated that GSCM was strongly balancing to other advanced management practices, and contributed to improving environmental performance.

Zhu et al. [30a] evaluated GSCM practices relating GSCM to closing the supply chain loop for four Chinese industries (power generating, chemical/petroleum, electrical/electronic and automobile). They concluded that adoption of GSCM practices in different industrial contexts is not uniform across the four industries. Another study also by Zhu et al. [31] in China has evaluated and explained GSCM drivers, practices and performance among diverse Chinese manufacturing firms. They concluded that the higher environmental awareness and pressures in 
Chinese enterprise has not contributed into strong or higher GSCM practice adoption, let alone to improvements expected in some areas of performance.

Concern about the environmental issue has also rise the interest of researchers to investigate the adoption and implementation of GSCM practices in another Asian Countries such as Thailand, India and Malaysia. A study of Ninlawan et al. [2] in Thailand analyzed the recent green activities in computer parts' manufacturers and also measured the level of green supply chain management. The in-depth interview regarding green procurement, green manufacturing, green distribution, and reverse logistic has been conducted. The study conducted in India by Diabat and Govindan [32] identified the drivers influencing the implementation of GSCM using an Interpretive Structural Modeling (ISM) methodology and extracted 11 drivers collected through past literature: Certification of suppliers' environmental management system; environmental collaboration with suppliers; collaboration between product designers and suppliers to reduce and eliminate product environmental impacts; government regulation and legislation; green design; ISO 14001 certification; integrating quality environmental management into planning and operation process; reducing energy consumption; reusing and recycling materials and packaging, environmental collaboration with customers; and reverse logistics.

The concept of GSCM is relatively newer in Malaysia. Recent literature found that still lack of researchers study on GSCM adoption and implementation based on Malaysian context as a developing country. One study from Malaysia that has been carried out by Eltayeb and Zailani [33] has identified the four key drivers or motivators to green supply chain initiatives: Regulations, customer requirements, expected business gains, and social responsibility. Eltayeb et al. [34] analyzed the relationship between green supply chain initiatives and performance outcomes and identified the key initiatives (eco-design) that have positive effect on the four types of outcomes (environmental, economic, cost reductions, and intangible outcomes).

\subsection{Review of Previous Studies on Green Supply Chain Management}

The following is a review of previous literatures about issues related to GSCM and has been summarized into three sections which by manufacturing (various industry), by manufacturing (focus industry) and by Malaysian country.

Table 1 shows the previous studies of GSCM according to various industries in manufacturing. Most researchers used manufacturing industry as their sample of study in order to investigate the GSCM adoption and implementation either in developed and developing countries. Manufacturing is believed to be the main causes to the emerging environmental problems due to its traditional business operation. Various industries in manufacturing companies such as manufacturers in paper; textile and dyeing; chemicals, plastics and rubbers; metals; machinery and equipment manufacturing; electronics; automobile; printing; construction and others. Traditional polluting industries such as manufacturers in chemical, electrical and paper industries generally experience higher environmental pressure. Therefore, the manufacturing industry as traditional polluters tend to be the potential sample of study as they tend to implement GSCM practices.

Table 1. Summary of the previous studies of GSCM according to manufacturing industry (Various Industry)

\begin{tabular}{|l|l|l|l|l|}
\hline Year & Title/Author & Findings & Variables & Country \\
\hline 2011 & Drivers of Green & $\bullet$ The degree of green & Five potential & Germany \\
& Supply Chain & supplier assessment and & drivers of green & \\
& Management & green collaboration has & supply management & \\
& Performance: & direct influence on & performance: & \\
& Evidence from & environmental & $\bullet$ Green supply & \\
& Germany & performance. & management & \\
\hline
\end{tabular}


International Journal of Managing Value and Supply Chains (IJMVSC) Vol. 3, No. 1, March 2012

\begin{tabular}{|c|c|c|c|c|}
\hline & $\begin{array}{l}\text { Large, R.O. \& } \\
\text { Thomsen, C.G. }\end{array}$ & $\begin{array}{l}\text { - These two practices are } \\
\text { driven by the strategic } \\
\text { level of the purchasing } \\
\text { department and the level } \\
\text { of environmental } \\
\text { commitment of the firm. } \\
\text { - Commitment influences } \\
\text { green assessment directly, } \\
\text { the impact of commitment } \\
\text { on green collaboration is } \\
\text { mediated by the } \\
\text { capabilities of the } \\
\text { purchasing department. } \\
\text { - Environmental } \\
\text { performance has a positive } \\
\text { impact on purchasing } \\
\text { performance. }\end{array}$ & $\begin{array}{l}\text { capabilities } \\
\text { - The strategic } \\
\text { level of } \\
\text { purchasing } \\
\text { department } \\
\text { - The level of } \\
\text { environment } \\
\text { commitment } \\
\text { - The degree of } \\
\text { green supplier } \\
\text { assessment } \\
\text { - The degree of } \\
\text { green } \\
\text { collaboration } \\
\text { with suppliers } \\
\text { Performance: } \\
\text { Environmental } \\
\text { performance and } \\
\text { purchasing } \\
\text { performance }\end{array}$ & \\
\hline 2011 & $\begin{array}{l}\text { Is ISO } 14001 \text { a } \\
\text { gateway to more } \\
\text { advanced voluntary } \\
\text { action? The case of } \\
\text { green supply chain } \\
\text { management } \\
\text { Arimura et al. }\end{array}$ & $\begin{array}{l}\text { ISO } 14001 \text { contributed to } \\
\text { GSCM practices which } \\
\text { facilities with ISO } 14001 \\
\text { are } 40 \% \text { more likely to } \\
\text { evaluate their suppliers' } \\
\text { environmental } \\
\text { performance and 50\% } \\
\text { more likely to ask their } \\
\text { suppliers undertake } \\
\text { specific environmental } \\
\text { practices. } \\
\text { - Government program of } \\
\text { encouraging EMS } \\
\text { adoption indirectly } \\
\text { influences ISO 14001 } \\
\text { adopters to implement } \\
\text { GSCM practices. }\end{array}$ & $\begin{array}{l}\text { - } \text { ISO } 14001 \\
\text { - } \text { Facility's GSCM } \\
\text { practices }\end{array}$ & Japan \\
\hline 2011 & $\begin{array}{l}\text { The Influence of } \\
\text { Greening the } \\
\text { Suppliers and Green } \\
\text { Innovation on } \\
\text { Environmental } \\
\text { Performance and } \\
\text { Competitive } \\
\text { Advantage in Taiwan } \\
\text { Chiou, T.Y. et al. }\end{array}$ & $\begin{array}{l}\text { - Greening the suppliers } \\
\text { leads to green innovation } \\
\text { and competitive } \\
\text { advantage. } \\
\text { - The finding also support } \\
\text { that the intervening } \\
\text { variables of green } \\
\text { innovation contribute to } \\
\text { competitive advantage. } \\
\text { Taiwanese companies } \\
\text { have started to implement } \\
\text { actions toward greening } \\
\text { their suppliers and } \\
\text { developing greener } \\
\text { products and }\end{array}$ & $\begin{array}{l}\text { - Green innovation } \\
\text { (Product } \\
\text { innovation, } \\
\text { Process } \\
\text { innovation, } \\
\text { Managerial } \\
\text { Innovation) } \\
\text { - Environmental } \\
\text { performance } \\
\text { - Competitive } \\
\text { advantage }\end{array}$ & Taiwan \\
\hline
\end{tabular}


International Journal of Managing Value and Supply Chains (IJMVSC) Vol. 3, No. 1, March 2012

\begin{tabular}{|c|c|c|c|c|}
\hline & & manufacturing process. & & \\
\hline 2011 & $\begin{array}{l}\text { Research on the } \\
\text { Performance } \\
\text { Measurement of } \\
\text { Green Supply Chain } \\
\text { Management in } \\
\text { China } \\
\text { Yan Li }\end{array}$ & $\begin{array}{l}\text { - Chinese enterprises have } \\
\text { tried to implement a } \\
\text { variety of GSCM practices } \\
\text { to improve their } \\
\text { environmental } \\
\text { performance in response to } \\
\text { the export philosophy. } \\
\text { - Internal environmental } \\
\text { management, } \\
\text { (commitment from top- } \\
\text { level managers and } \\
\text { support from mid-level } \\
\text { managers) will be } \\
\text { necessary for development } \\
\text { of any GSCM programs in } \\
\text { China. }\end{array}$ & $\begin{array}{l}\text { Eco-design level; } \\
\text { green purchasing } \\
\text { level; green } \\
\text { manufacturing } \\
\text { capacity; green } \\
\text { marketing and } \\
\text { consumption; } \\
\text { recycling products } \\
\text { processing ability; } \\
\text { level of information } \\
\text { technology; } \\
\text { comprehensive level }\end{array}$ & China \\
\hline 2011 & $\begin{array}{l}\text { Sustainable } \\
\text { Production: Practices } \\
\text { and Determinant } \\
\text { Factors of Green } \\
\text { Supply Chain } \\
\text { Management of } \\
\text { Chinese Companies } \\
\text { Liu, X. et al. }\end{array}$ & $\begin{array}{l}\text { - Chinese companies are } \\
\text { still at a preliminary stage } \\
\text { of GSCM practices. } \\
\text { - Their environmental } \\
\text { management in } \\
\text { cooperation with external } \\
\text { members of the supply } \\
\text { chain is very marginal. } \\
\text { - A company's LGSCM is } \\
\text { significantly and } \\
\text { positively associated with } \\
\text { external pressures from } \\
\text { regulatory, domestic } \\
\text { clients and business } \\
\text { competitors. } \\
\text { - A company's learning } \\
\text { capacity in internal factors } \\
\text { greatly measured LGCM. }\end{array}$ & $\begin{array}{l}\text { - External } \\
\text { pressures } \\
\text { - Internal factors } \\
\text { - GSCM practices } \\
\text { - Controls } \\
\text { (company's size, } \\
\text { industrial sector) }\end{array}$ & China \\
\hline 2011 & $\begin{array}{l}\text { Evaluating Green } \\
\text { Supply Chain } \\
\text { Management among } \\
\text { Chinese } \\
\text { Manufacturers from } \\
\text { the Ecological } \\
\text { Modernization } \\
\text { Perspective } \\
\text { Zhu et al. }\end{array}$ & $\begin{array}{l}\text { The results highlighted the } \\
\text { varying pace of Chinese } \\
\text { manufacturers to } \\
\text { ecological modernize with } \\
\text { GSCM practices and the } \\
\text { significance of regulatory } \\
\text { pressure to diffuse the } \\
\text { practices adoption by } \\
\text { Chinese manufacturing } \\
\text { industry }\end{array}$ & $\begin{array}{l}\text { Awareness of } \\
\text { environmental } \\
\text { regulations/ policies }\end{array}$ & China \\
\hline 2011 & $\begin{array}{l}\text { The impact of green } \\
\text { supply chain } \\
\text { practices on company } \\
\text { performance: the } \\
\text { case of 3PLs }\end{array}$ & $\begin{array}{l}\text { - Still limited adoption of } \\
\text { GSCP among the 3PLs } \\
\text { service providers, } \\
\text { sometimes oriented only to } \\
\text { a compliance with } \\
\text { environmental regulations. }\end{array}$ & 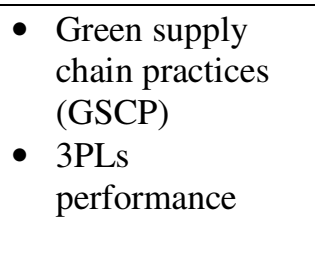 & Italy \\
\hline
\end{tabular}


International Journal of Managing Value and Supply Chains (IJMVSC) Vol. 3, No. 1, March 2012

\begin{tabular}{|c|c|c|c|c|}
\hline & Cagno et al. & $\begin{array}{l}\text { - Some participant have } \\
\text { shown a pro-active attitude } \\
\text { and gained significant } \\
\text { benefit from the adoption } \\
\text { of GSCP. }\end{array}$ & & \\
\hline 2010 & $\begin{array}{l}\text { Green Supply Chain } \\
\text { Management in } \\
\text { Leading } \\
\text { Manufacturers- Case } \\
\text { Studies in Japanese } \\
\text { Large Companies } \\
\text { Zhu et al. }\end{array}$ & $\begin{array}{l}\text { - Japanese large } \\
\text { manufacturers implement } \\
\text { one key GSCM practice, } \\
\text { internal environmental } \\
\text { management at a } \\
\text { significantly higher level } \\
\text { than Chinese } \\
\text { manufacturers. } \\
\text { - The four other GSCM } \\
\text { practices were } \\
\text { implemented at similar } \\
\text { levels when compared to } \\
\text { Chinese manufacturers. } \\
\text { - It was found that large } \\
\text { Japanese companies have } \\
\text { made significant } \\
\text { improvements for } \\
\text { environmental and } \\
\text { financial performance but } \\
\text { not for operational } \\
\text { performance. }\end{array}$ & $\begin{array}{l}\text { - GSCM drivers } \\
\text { (Normative } \\
\text { pressure, } \\
\text { Coercive } \\
\text { pressure, Mimetic } \\
\text { pressure) } \\
\text { - GSCM practices } \\
\text { (Internal \& } \\
\text { external } \\
\text { dimensions) } \\
\text { GSCM } \\
\text { performance } \\
\text { (Economic, } \\
\text { financial, } \\
\text { operational) }\end{array}$ & Japan \\
\hline 2009 & $\begin{array}{l}\text { An Empirical Study } \\
\text { of Green Supply } \\
\text { Chain Management } \\
\text { Practices Amongst } \\
\text { UK Manufacturers } \\
\text { Holt, D. \& } \\
\text { Ghobadian, A. }\end{array}$ & $\begin{array}{l}\text { - Manufacturers identify the } \\
\text { greatest pressure to } \\
\text { increase environmental } \\
\text { performance is legislation } \\
\text { and internal drivers (IDs). } \\
\text { - GSCM practices among } \\
\text { the UK manufacturers are } \\
\text { focusing on internal higher } \\
\text { risk, descriptive activities. } \\
\text { - Environmental attitude } \\
\text { (EA) is a key predictor of } \\
\text { GSCM activity and those } \\
\text { organizations that have } \\
\text { progressive attitude are } \\
\text { also operationally very } \\
\text { active. }\end{array}$ & $\begin{array}{l}\text { External drivers } \\
\text { (Legislation, } \\
\text { competitive, } \\
\text { supply chain, } \\
\text { societal) } \\
\text { - Internal drivers }\end{array}$ & UK \\
\hline 2009 & $\begin{array}{l}\text { ISO } 14001 \text { in } \\
\text { environmental supply } \\
\text { chain practices } \\
\text { Nawrocka et al. }\end{array}$ & $\begin{array}{l}\text { - ISO } 14001 \text { has a } \\
\text { facilitating role in the } \\
\text { environmental activities } \\
\text { between a customer and a } \\
\text { supplier. } \\
\text { - Closer relationship with } \\
\text { suppliers was seen as } \\
\text { beneficial both for the } \\
\text { successful outcomes of } \\
\text { projects and as a facilitator }\end{array}$ & 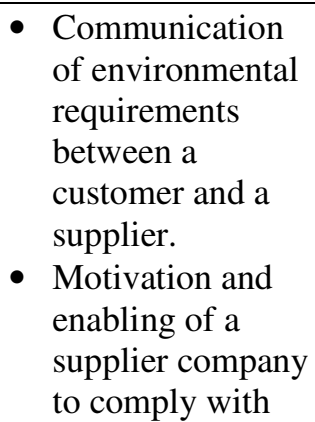 & Sweden \\
\hline
\end{tabular}


International Journal of Managing Value and Supply Chains (IJMVSC) Vol. 3, No. 1, March 2012

\begin{tabular}{|c|c|c|c|c|}
\hline & & $\begin{array}{l}\text { for environmental work. } \\
\text { The purchasing function, } \\
\text { and its interplay with the } \\
\text { environmental function } \\
\text { and other company } \\
\text { functions, was seen as } \\
\text { important for engaging in } \\
\text { supply chain activities }\end{array}$ & $\begin{array}{l}\text { the requirements. } \\
\text { Mechanisms for } \\
\text { control and } \\
\text { follow-up. }\end{array}$ & \\
\hline 2008 & $\begin{array}{l}\text { Green Supply Chain } \\
\text { Management } \\
\text { Implications for } \\
\text { "Closing the Loop" } \\
\text { Zhu et al. }\end{array}$ & $\begin{array}{l}\text { - Investment recovery } \\
\text { seemed to get less } \\
\text { attention in China. } \\
\text { - However, more Chinese } \\
\text { manufacturing have } \\
\text { realized the importance of } \\
\text { GSCM due to potential } \\
\text { regulatory pressure in } \\
\text { China as well as pending } \\
\text { marketing pressure from } \\
\text { Europe when they export } \\
\text { products. }\end{array}$ & $\begin{array}{l}\text { GSCM dimensions: } \\
\text { Internal } \\
\text { environmental } \\
\text { management, green } \\
\text { purchasing, } \\
\text { customer } \\
\text { cooperation with } \\
\text { environmental } \\
\text { concern, investment } \\
\text { recovery, and eco- } \\
\text { design }\end{array}$ & China \\
\hline 2008 & $\begin{array}{l}\text { Drivers for the } \\
\text { participation of small } \\
\text { and medium-sized } \\
\text { suppliers in green } \\
\text { supply chain } \\
\text { initiatives } \\
\text { Su-Yol Lee }\end{array}$ & $\begin{array}{l}\text { - Buyer environmental } \\
\text { requirements and support } \\
\text { have positive effect to } \\
\text { their suppliers' willingness } \\
\text { to participate in green } \\
\text { supply chain initiatives. } \\
\text { - The government can play } \\
\text { an important role in } \\
\text { motivating these suppliers. } \\
\text { - The more slow resources } \\
\text { and organizational } \\
\text { capabilities suppliers had, } \\
\text { the more willingly they } \\
\text { were to participate in those } \\
\text { initiatives. }\end{array}$ & $\begin{array}{l}\text { Buyer GSC } \\
\text { practices, } \\
\text { government } \\
\text { involvement, GSC } \\
\text { readiness, GSC } \\
\text { participation }\end{array}$ & $\begin{array}{l}\text { South } \\
\text { Korea }\end{array}$ \\
\hline 2008 & $\begin{array}{l}\text { Influences, practices } \\
\text { and opportunities for } \\
\text { environmental supply } \\
\text { chain } \\
\text { management in Nova } \\
\text { Scotia SMEs } \\
\text { Raymond } \text { et al. }\end{array}$ & $\begin{array}{l}\text { - Small suppliers and } \\
\text { medium-sized enterprises, } \\
\text { have difficulties in } \\
\text { allocating resources to } \\
\text { initiatives that are not } \\
\text { viewed as directly related } \\
\text { to their core function, } \\
\text { namely manufacturing the } \\
\text { product or providing the } \\
\text { service. } \\
\text { - This study clearly } \\
\text { demonstrated that } \\
\text { opportunities exist to } \\
\text { reduce greenhouse gas } \\
\text { emissions and solid waste } \\
\text { within supply chains. }\end{array}$ & $\begin{array}{ll}\text { - Environmental } \\
\text { performance } \\
\text { - Environmental } \\
\text { issues }\end{array}$ & Canada \\
\hline 2005 & Green Supply Chain & - Chinese enterprises have & - GSCM drivers & China \\
\hline
\end{tabular}


International Journal of Managing Value and Supply Chains (IJMVSC) Vol. 3, No. 1, March 2012

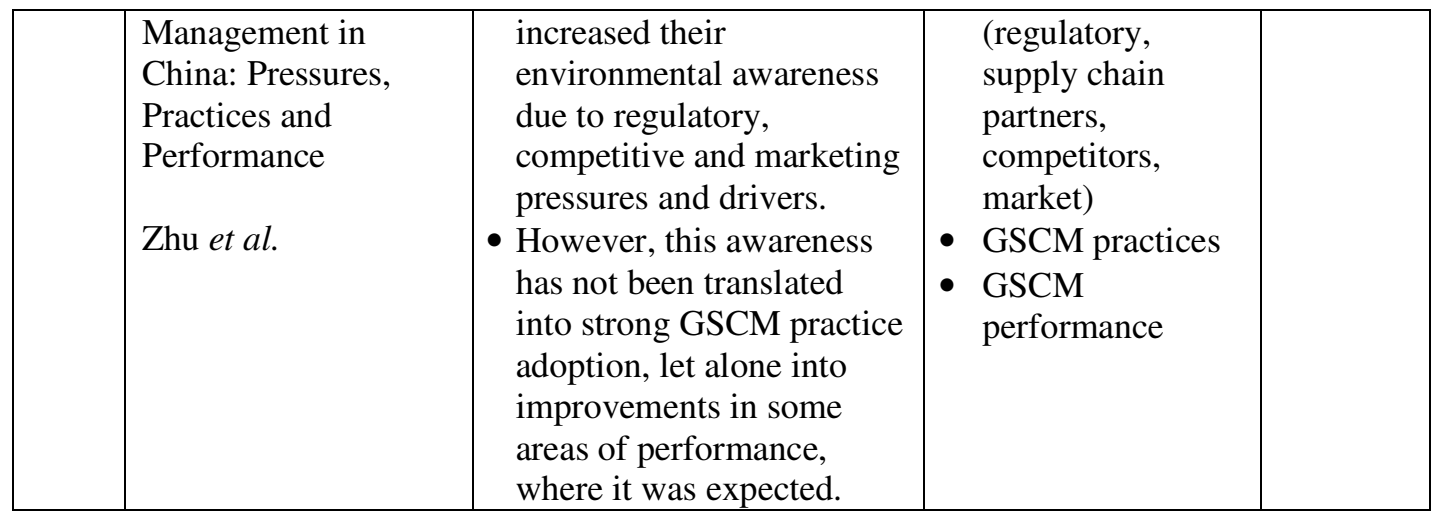

Meanwhile, Table 2 also presents the previous studies of GSCM among manufacturing industry but it only study certain industries from the various type of industries. These researchers had focused to specific industry in order to get depth understanding of GSCM practices without comparing to different industries.

Table 2. Summary of the previous studies of GSCM according to manufacturing industry (Focus Industry)

\begin{tabular}{|c|c|c|c|c|}
\hline Year & Title/Author & Findings & Variables & $\begin{array}{l}\text { Country/ } \\
\text { Industry }\end{array}$ \\
\hline 2011 & $\begin{array}{l}\text { The Influence of } \\
\text { Green Practices on } \\
\text { Supply Chain } \\
\text { Performance: A } \\
\text { Case Study } \\
\text { Approach } \\
\text { Azevedo, S.G. et } \\
\text { al. }\end{array}$ & $\begin{array}{l}\text { - The critical green } \\
\text { practices are 'reverse } \\
\text { logistic (Downstream)', } \\
\text { 'minimizing waste and } \\
\text { ISO 140001 (Focal } \\
\text { Company)'. } \\
\text { - The most widely adopted } \\
\text { green practices in the case } \\
\text { study companies: [ISO } \\
\text { 140001, minimizing } \\
\text { waste, decreasing the } \\
\text { consumption of hazardous } \\
\text { and toxic materials-Focal } \\
\text { company] and [reverse } \\
\text { logistic- Downstream]. } \\
\text { The performance } \\
\text { measures that were most } \\
\text { extensively used in the } \\
\text { case study companies are: } \\
\text { Operational (customer } \\
\text { satisfaction, quality) and } \\
\text { economic (cost). }\end{array}$ & $\begin{array}{l}\text { - Green } \\
\text { practices: } \\
\text { Upstream } \\
\text { (suppliers), } \\
\text { Focal company } \\
\text { (internal } \\
\text { operations, } \\
\text { Downstream } \\
\text { (customers) } \\
\text { - Supply chain } \\
\text { performance: } \\
\text { Economic, } \\
\text { Operational, } \\
\text { Environmental }\end{array}$ & $\begin{array}{c}\text { Portuguese; } \\
\text { Automotive } \\
\text { sector }\end{array}$ \\
\hline 2011 & $\begin{array}{l}\text { The } \\
\text { Implementation of } \\
\text { Green Supply } \\
\text { Chain } \\
\text { Management } \\
\text { Practices in } \\
\text { Electronics }\end{array}$ & $\begin{array}{l}\text { For GSCM practices, } \\
\text { three products } \\
\text { (semiconductor, hard disk } \\
\text { drive, print circuit board) } \\
\text { with carrying out from } \\
\text { some degree to full } \\
\text { adoption. }\end{array}$ & $\begin{array}{l}\text { - } \text { GSCM } \\
\text { practices } \\
\text { - GSCM } \\
\text { performance } \\
\text { - } \text { GSCM pressure } \\
\text { (market, } \\
\text { regulatory, }\end{array}$ & $\begin{array}{l}\text { Thailand; } \\
\text { Electronic } \\
\text { (Computer } \\
\text { Part) } \\
\text { sector }\end{array}$ \\
\hline
\end{tabular}


International Journal of Managing Value and Supply Chains (IJMVSC) Vol. 3, No. 1, March 2012

\begin{tabular}{|c|c|c|c|c|}
\hline & $\begin{array}{l}\text { Industry } \\
\text { Ninlawan et al. }\end{array}$ & $\begin{array}{l}\text { Both environmental and } \\
\text { positive economic were in } \\
\text { relatively significant in } \\
\text { GSCM performance. } \\
\text { - Pressure from } \\
\text { environmental regulations } \\
\text { is the highest driver, } \\
\text { followed by export } \\
\text { pressure for Thai } \\
\text { electronics supply chain } \\
\text { to implement GSCM. }\end{array}$ & competition) & \\
\hline 2011 & $\begin{array}{l}\text { An Analysis of the } \\
\text { Drivers Affecting } \\
\text { the } \\
\text { Implementation of } \\
\text { Green Supply } \\
\text { Chain } \\
\text { Management } \\
\text { Diabat \& } \\
\text { Govindan }\end{array}$ & $\begin{array}{l}\text { Government regulation } \\
\text { and legislation and } \\
\text { reverse logistics are } \\
\text { significant drivers to } \\
\text { achieve the collaboration } \\
\text { between product } \\
\text { designers and suppliers to } \\
\text { reduce and eliminate } \\
\text { product environmental } \\
\text { impact driver, which to } \\
\text { achieving the GSCM } \\
\text { certification of suppliers' } \\
\text { environmental } \\
\text { management system } \\
\text { driver. }\end{array}$ & $\begin{array}{l}\text { Drivers of } \\
\text { GSCM (11 } \\
\text { types of drivers } \\
\text { involved in this } \\
\text { study, collected } \\
\text { through several } \\
\text { previous } \\
\text { studies) }\end{array}$ & $\begin{array}{l}\text { India; } \\
\text { Aluminium } \\
\text { sector }\end{array}$ \\
\hline 2010 & $\begin{array}{l}\text { A taxonomy of } \\
\text { green supply chain } \\
\text { management } \\
\text { capability among } \\
\text { electronics-related } \\
\text { manufacturing } \\
\text { firms in Taiwan } \\
\text { Shang et al. }\end{array}$ & $\begin{array}{l}\text { The green marketing } \\
\text { oriented group performed } \\
\text { best. } \\
\text { - According to the } \\
\text { resource-based view } \\
\text { (RBV), the capability of } \\
\text { the green marketing } \\
\text { oriented group was } \\
\text { considered to be the use } \\
\text { of a collection of } \\
\text { resources that enables it } \\
\text { to successfully compete } \\
\text { against competitors } \\
\text { The importance of green } \\
\text { marketing as a GSCM } \\
\text { capability and strategic } \\
\text { asset/critical resources for } \\
\text { electronics-related } \\
\text { manufacturing firms to } \\
\text { obtain a competitive edge } \\
\text { is therefore highlighted in } \\
\text { this study. }\end{array}$ & $\begin{array}{l}\text { - Green } \\
\text { manufacturing } \\
\text { and packaging } \\
\text { - Environmental } \\
\text { participation } \\
\text { - Green } \\
\text { marketing } \\
\text { - Green suppliers } \\
\text { - Green stock } \\
\text { - Green eco- } \\
\text { design. }\end{array}$ & $\begin{array}{l}\text { Taiwan; } \\
\text { Electronic } \\
\text { Industry }\end{array}$ \\
\hline 2008 & $\begin{array}{l}\text { Green Supply } \\
\text { Chain } \\
\text { Management in } \\
\text { the Electronic }\end{array}$ & $\begin{array}{l}\text { The enterprises would } \\
\text { emphasize on supplier } \\
\text { management performance } \\
\text { in the crucial role of }\end{array}$ & $\begin{array}{l}\text { Approach for } \\
\text { implementing } \\
\text { GSCM: Supplier } \\
\text { management, }\end{array}$ & $\begin{array}{l}\text { Taiwan; } \\
\text { Electronic } \\
\text { Industry }\end{array}$ \\
\hline
\end{tabular}


International Journal of Managing Value and Supply Chains (IJMVSC) Vol. 3, No. 1, March 2012

\begin{tabular}{|c|c|c|c|c|}
\hline & $\begin{array}{l}\text { Industry } \\
\text { Hsu, C.W. \& Hu, } \\
\text { A.H. }\end{array}$ & $\begin{array}{l}\text { implementing GSCM. } \\
\text { The most important } \\
\text { approaches included } \\
\text { establishing an } \\
\text { environmental database of } \\
\text { products, asking for } \\
\text { product testing report and } \\
\text { top management support. }\end{array}$ & $\begin{array}{l}\text { product } \\
\text { recycling, } \\
\text { organizational } \\
\text { involvement, life } \\
\text { cycle } \\
\text { management }\end{array}$ & \\
\hline 2008 & $\begin{array}{l}\text { The Driver of } \\
\text { Green Innovation } \\
\text { and Green Image } \\
\text { - Green Core } \\
\text { Competence } \\
\text { Yu-Shan Chen }\end{array}$ & $\begin{array}{l}\text { Green core competences } \\
\text { of firms were positively } \\
\text { linked to their green } \\
\text { innovation performance } \\
\text { and green images. } \\
\text { Two types of green } \\
\text { innovation performance } \\
\text { had partial mediation } \\
\text { effects between green } \\
\text { core competences and } \\
\text { green images of firms. } \\
\text { Green core competence, } \\
\text { two types of green } \\
\text { innovation performance, } \\
\text { and green images of } \\
\text { medium \& small } \\
\text { enterprises (SMEs) were } \\
\text { all significantly less than } \\
\text { those of large enterprises } \\
\text { in the information and } \\
\text { electronics industry in } \\
\text { Taiwan. }\end{array}$ & $\begin{array}{l}\text { - Green core } \\
\text { competence } \\
\text { - Green } \\
\text { innovation: } \\
\text { green product } \\
\text { innovation } \\
\text { performance, } \\
\text { green process } \\
\text { innovation } \\
\text { performance, } \\
\text { and green } \\
\text { images } \\
\text { information }\end{array}$ & $\begin{array}{l}\text { Taiwan; } \\
\text { Electronics } \\
\text { industry }\end{array}$ \\
\hline 2007 & $\begin{array}{l}\text { An empirical } \\
\text { study of the } \\
\text { implementation of } \\
\text { green supply chain } \\
\text { management } \\
\text { practices in the } \\
\text { electrical and } \\
\text { electronic industry } \\
\text { and their } \\
\text { relation to } \\
\text { organizational } \\
\text { performances } \\
\text { Chien, M. K. and } \\
\text { Shih, L. H. }\end{array}$ & $\begin{array}{l}\text { Original equipment } \\
\text { manufacturing and original } \\
\text { designing and manufacturing } \\
\text { manufacturers have adopted } \\
\text { green procurement and green } \\
\text { manufacturing practices in } \\
\text { response to the current trend } \\
\text { of international green issues } \\
\text { and have caused positive } \\
\text { environmental and financial } \\
\text { performances for the } \\
\text { respective companies. }\end{array}$ & $\begin{array}{l}\text { Environmental } \\
\text { regulations, } \\
\text { External } \\
\text { stakeholders, } \\
\text { GSCM practices, } \\
\text { Environmental } \\
\text { performance, } \\
\text { Financial } \\
\text { performance }\end{array}$ & $\begin{array}{l}\text { Taiwan; } \\
\text { Electrical and } \\
\text { electronic } \\
\text { industry }\end{array}$ \\
\hline 2007 & $\begin{array}{l}\text { Greening the } \\
\text { automotive supply } \\
\text { chain: a } \\
\text { relationship } \\
\text { perspective } \\
\text { Simpson et al. }\end{array}$ & $\begin{array}{l}\text { Traditional operations } \\
\text { theory on inter- } \\
\text { organizational } \\
\text { performance } \\
\text { improvement is just as } \\
\text { relevant to the use of } \\
\text { environmental }\end{array}$ & $\begin{array}{l}\text { - } \text { Customer } \\
\text { environmental } \\
\text { performance } \\
\text { requirements } \\
\text { - Supplier } \\
\text { environmental } \\
\text { commitment } \\
\end{array}$ & $\begin{array}{l}\text { Australia; } \\
\text { Automotive } \\
\text { industry }\end{array}$ \\
\hline
\end{tabular}


International Journal of Managing Value and Supply Chains (IJMVSC) Vol. 3, No. 1, March 2012

\begin{tabular}{|l|l|l|}
\hline & performance & \\
requirements. & \\
& Suppliers were found to & \\
be more responsive to & \\
their customers' & environmental \\
& performance requirements & \\
& where increasing levels of & \\
& relationship-specific & \\
& investment occurred. & \\
\hline
\end{tabular}

Based on Table 3, the previous studies of GSCM in Malaysia are presented. From the table below, it shows clearly how many researchers were attempt to promoting this relatively new concept in Malaysia. As a matter of fact, Malaysia is moving forward to be an industrialized economy. Malaysia shifted from material production to manufacturing. The manufacturing industry remained to be an important contributor to Malaysian's economy in recent years. But, the rapid industrialization had caused negative impact on the environment because of the increase in the pollution, waste, and rapid consumption of natural resources [35]. It is clearly showed that manufacturing industry is the most contributors to the environmental problem. Environmental issues have become very important issues of concern for the Malaysian government and the public [34]. With regards to environmental concern into manufacturing industry, it is necessary for the study to investigate the level of adoption and implementation GSCM among certified companies in Malaysia.

However, the studies in Malaysia are still lacking and the findings are also not conclusive. Most researchers conducted study on GSCM practices in several Asian countries such as China may have similar market and social-cultural situation with Malaysia. However, as stressed by Christmann and Taylor [36], different industries sectors of different countries are facing different pressures. It is also supported by Rao [26] stated the level and mode of implementation of GSCM practices vary significantly in different countries. It means manufacturing industry in Malaysia is differed to other countries due to different background or culture.

In addition, a lot of companies in Malaysia are still behind and yet to adopt the green supply chain concept in their business operation [37]. According to Eltayeb and Zailani [35], Malaysian fully owned companies have lower level of adoption and participation in green supply chain practices compare to foreign based companies and MNC (Multinational Company). The barriers in the adoption of GSCM in Malaysia depend on the companies' size [19] and high cost of adopting green supply chain practice [25]. Other than that, the establishment of the Ministry of Energy, Green Technology and Water on April, 92009 by the Prime Minister, Y.A.B Datuk Sri Najib Tun Razak has pushed business organization to adopt a green culture in their business operation. However, the level of readiness to adopt green technology among Malaysian manufacturing companies is still unclear. Therefore, given of these above issues, the future study is required to investigate in more depth the adoption and implementation of GSCM in Malaysia and also other variables that relevant to the field.

Table 3. Summary of the previous studies of GSCM in Malaysia

\begin{tabular}{|c|l|l|l|l|}
\hline Year & \multicolumn{1}{|c|}{ Title/Author } & \multicolumn{1}{c|}{ Findings } & \multicolumn{1}{c|}{ Variables } & \multicolumn{1}{c|}{ Area } \\
\hline 2011 & Green Supply Chain & $\bullet$ Eco-design has & $\bullet$ Green supply & Manufacturing \\
& Initiatives among & significant positive effect & chain & (EMS IS0 \\
& Certified Companies & on the four types of & initiatives & 14001Certified \\
& in Malaysia and & outcomes. & (Eco-design, & Firms) \\
& Environmental & $\bullet$ Reverse logistic was & green & \\
\hline
\end{tabular}


International Journal of Managing Value and Supply Chains (IJMVSC) Vol. 3, No. 1, March 2012

\begin{tabular}{|c|c|c|c|c|}
\hline & $\begin{array}{l}\text { Sustainability: } \\
\text { Investigating the } \\
\text { Outcomes } \\
\text { Eltayeb, T.K. et al. }\end{array}$ & $\begin{array}{l}\text { found to have significant } \\
\text { positive effect on cost } \\
\text { reductions only, while } \\
\text { green purchasing was not } \\
\text { found to have significant } \\
\text { effect on any of the four } \\
\text { types of outcomes. }\end{array}$ & $\begin{array}{l}\text { purchasing, } \\
\text { reverse } \\
\text { logistic- } \\
\text { commonly } \\
\text { adopted in } \\
\text { Malaysia) } \\
\text { - Green supply } \\
\text { chain } \\
\text { outcomes } \\
\text { (Environment } \\
\text { al, economic, } \\
\text { operational, } \\
\text { intangible) }\end{array}$ & \\
\hline 2011 & $\begin{array}{l}\text { Greening of the } \\
\text { Supply Chain } \\
\text { Through Supply } \\
\text { Chain Initiatives } \\
\text { towards } \\
\text { Environmental } \\
\text { Sustainability } \\
\text { Al Khidir, T. \& } \\
\text { Zailani, S.H.M. }\end{array}$ & $\begin{array}{l}\text { - Expected business } \\
\text { benefits have the greatest } \\
\text { influence on green } \\
\text { supply chain initiatives } \\
\text { followed by regulations } \\
\text { and customer pressures, } \\
\text { and finally social } \\
\text { responsibility. } \\
\text { - Malaysian firms tend to } \\
\text { respond regulations and } \\
\text { customer pressures that } \\
\text { require them to adopt } \\
\text { green supply chain } \\
\text { initiatives but the } \\
\text { decision is based mainly } \\
\text { on evaluating the benefits } \\
\text { that return to the firms } \\
\text { from adopting such } \\
\text { initiatives. }\end{array}$ & $\begin{array}{l}\text { Drivers: } \\
\text { Regulations, } \\
\text { customer } \\
\text { requirements, } \\
\text { expected } \\
\text { business gains, } \\
\text { social } \\
\text { responsibility }\end{array}$ & $\begin{array}{l}\text { Manufacturing } \\
\text { (EMS IS0 } \\
\text { 14001Certified } \\
\text { Firms) }\end{array}$ \\
\hline
\end{tabular}

Based on these tables, the authors can see that most studies were explored on developed countries and more focus to the manufacturing area. It can be concluded that most developed countries are chosen because they were facing a lot of environmental problems due to the greater economic consumption. Then, the manufacturing industry can be seen as the major contributor to the environmental problems [34].

\section{RESEARCH DIRECTION}

Green supply chain management continues to be an important research agenda among the researchers. However, there is still limited of studies to investigate GSCM adoption and implementation in developing countries. Therefore, our research direction will be focus on ISO 14001 certified manufacturing firms in Malaysia context in order to extend the study about GSCM in more depth. ISO 14001 certified firms will be focused because they are expected to be involved in the adoption of GSCM practices. This is supported by the studies of Darnall et al. [38] and Zhu et al. [30b]. The research direction of this paper is showed in Figure 1. 


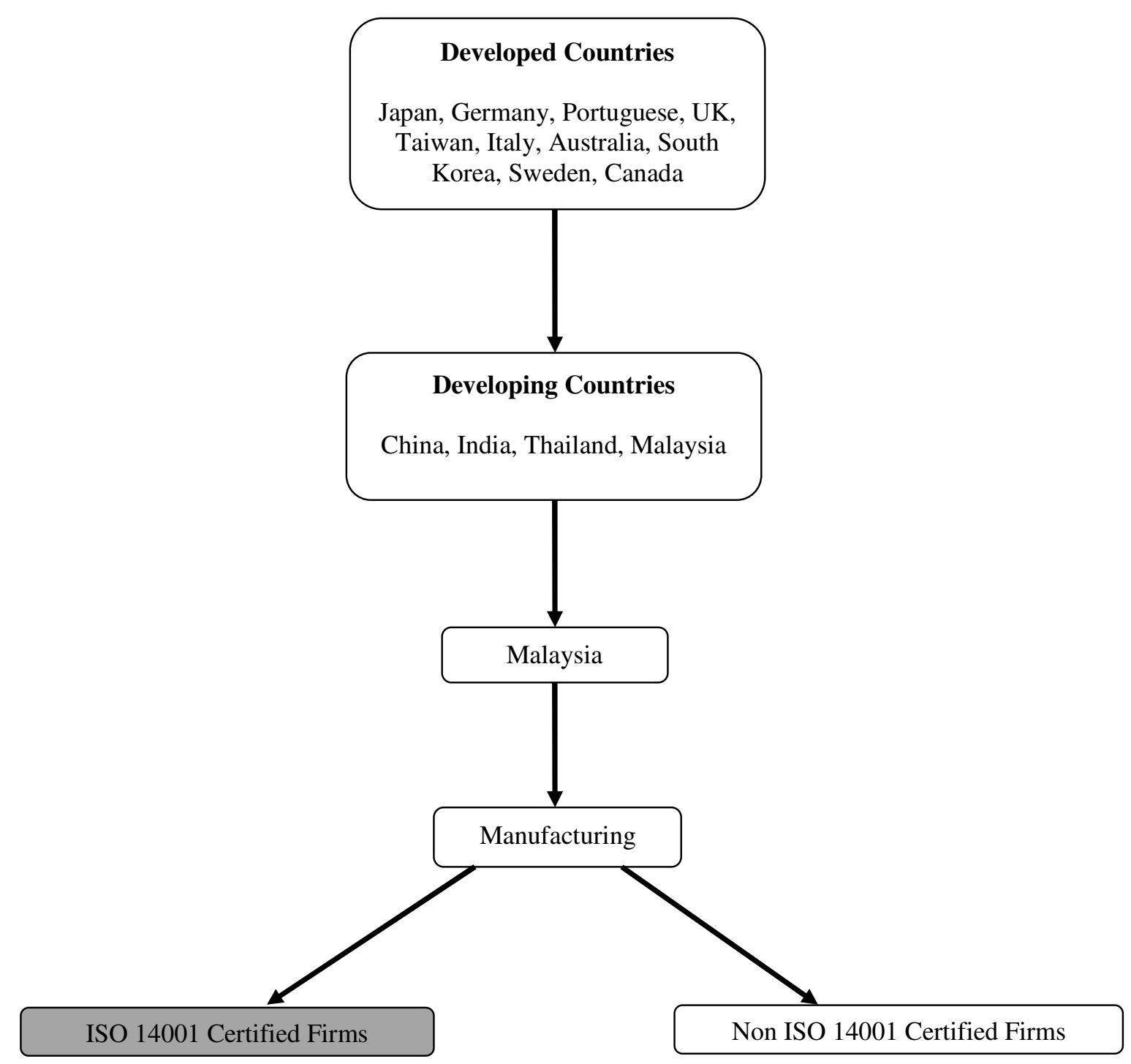

Figure 1. Research direction framework

\section{Conclusions}

The purpose of this paper is to discuss an overview of the development of GSCM literature in a developed countries and developing countries. Although some studies in the literature discussed the GSCM implementation includes drivers, practices, and performance over the world, but there has still little research about the GSCM implementation and adoption in developing countries especially Malaysia. Further study still required for more understanding toward the adoption and implementation of GSCM and also the organization awareness level on environmental problems that caused by their business operation. 
International Journal of Managing Value and Supply Chains (IJMVSC) Vol. 3, No. 1, March 2012

\section{ACKNOWLEDGEMENTS}

The authors would like to thank to the Faculty of Management and Human Resource Development, GUP research grant Vot.Q.J130000.7129.03J72 (MOHE) and UTM Johor Bahru.

\section{REFERENCES}

[1] Shultz, C.J.II \& Holbrook, M.B., (1999) "Marketing and Tragedy of the Commons: A Synthesis Commentary and Analysis for Action”, Journal of Public Policy and Marketing, Vol. 18, No. 2, pp 218-29.

[2] Ninlawan, C., Seksan, P., Tossapol, K., \& Pilada, W., (2011) "The Implementation of Green Supply Chain Management Practices in Electronics Industry", Proceedings of the International Multiconference of Engineers and Computer Scientists, 3.

[3] Zhu, Q. \& Sarkis, J., (2004) "Relationships between operational practices and performance among early adopters of green supply chain management practices in Chinese manufacturing enterprises", Journal of Operations Management, 22, pp 265-289.

[4] Beamon, B. M., (1999) "Designing the green supply chain", Logistics Information Management, Vol. 12, No. 4, pp 332-342.

[5] Zhu, Q., Geng, Y., Fujita, T., \& Hashimoto, S., (2010) "Green Supply Chain Management in Leading Manufacturers: Case Studies in Japanese Large Companies", Management Research Review, Vol. 33, No. 4, pp 380-392.

[6] Fortes, J., (2009) “Green Supply Chain Management: A Literature Review”, Otago Management Graduate Review, 7, pp 51-62.

[7] Srivastava, S.K., (2007) "Green supply-chain management: a state-of-the-art literature review", International Journal of Management Reviews, Vol. 9, No. 1, pp 53-80.

[8] Rao, P. \& Holt, D., (2005) "Do green supply chains lead to competitiveness and economic performance?", International Journal of Operations and Production Management, Vol. 25, No. 9, pp 898-916.

[9] Zhu Q. \& Sarkis, J., (2006) “An inter-sectoral comparison of green supply chain management in China: drivers and practices”, Journal of Cleaner Production, Vol. 14, No. 5, pp 472-86.

[10] Large, R.O. \& Thomsen, C.G., (2011) "Drivers of Green Supply Chain Management Performance: Evidence from Germany", Journal of Purchasing and Supply Management, Vol. 17, pp 176-184.

[11] Azevedo, S.G., Carvalho, H., \& Machado, V.C., (2011) "The Influence of Green Practices on Supply Chain Performance: A Case Study Approach”, Transportation Research Part E, Vol. 47, pp 850-871.

[12] Chiou, T.Y., Chan, H.K., Lettice, F., \& Chung, S.H., (2011) "The Influence of Greening the Suppliers and Green Innovation on Environmental Performance and Competitive Advantage in Taiwan", Transportation Research Part E, 47, pp 822-836.

[13] Cagno, E., Guido, M.J.L., Perotti, S, \& Zorzini, M., (2011) "The impact of green supply chain practices on company performance: the case of 3PLs", Lancaster University Management School Working Paper, pp 1-31.

[14] Arimura, T.H., Darnalln N., Katayama, H., (2011) "Is ISO 14001 a gateway to more advanced voluntary action? The case of green supply chain management", Journal of Environmental Economics and Management, 61, pp 170-182.

[15] Hsu, C.W. \& Hu, A.H., (2008) "Green Supply Chain Management in the Electronic Industry", International Journal Environment Science Technology, Vol. 5, No. 2, pp 205-216.

[16] Shang, K.C., Lu, C.S., Li, S., (2010) "A taxonomy of green supply chain management capability among electronics-related manufacturing firms in Taiwan", Journal of Environmental Management, 91, pp 1218-1226. 
International Journal of Managing Value and Supply Chains (IJMVSC) Vol. 3, No. 1, March 2012

[17] Holt, D. \& Ghobadian, A., (2009) "An Empirical Study of Green Supply Chain Management Practices amongst UK Manufacturers”, Journal of Manufacturing Technology, Vol. 20, No. 7, pp 933-956.

[18] Nawrocka, D., Brorson, T., \& Lindhqvist, T., (2009) "ISO 14001 in environmental supply chain practices", Journal of Cleaner Production, 17, pp 1435-1443.

[19] Lee, S., (2008) "Drivers for the participation of small and medium-sized suppliers in green supply chain initiatives”, Supply Chain Management: An International Journal, Vol. 13, No. 3, pp 185-198.

[20] Raymond, P. C., Lopez, J., Marche, S, Perron, G.M., \& Wright, R., (2008) "Influences, practices and opportunities for environmental supply chain management in Nova Scotia SMEs", Journal of Cleaner Production, 16, pp 1561-1570.

[21] Chen, Y., (2008) "The Driver of Green Innovation and Green Image - Green Core Competence", Journal of Business Ethics, 81, pp 531-543.

[22] Chien, M. K.\& Shih, L. H., (2007) "An empirical study of the implementation of green supply chain management practices in the electrical and electronic industry and their relation to organizational performances", Int. J. Environ. Sci. Tech., Vol. 4, No. 3, pp 383-394.

[23] Simpson, D., Power, D. \& Samson, D., (2007) "Greening the automotive supply chain: a relationship perspective", International Journal of Operations \& Production Management, Vol. 27, No. 1, pp 28-48.

[24] Vachon, S. \& Klassen, R.D., (2006) "Extending green practices across the supply chain: the impact of upstream and downstream integration", International Journal of Operations \& production Management, Vol. 26, No. 7, pp 795-821.

[25] Anbumozhi, V. \& Kanada, Y., (2005) "Greening the production and supply chains in Asia: is there a role for voluntarily initiatives?”, IGES Kansai Research Center Discussion Paper, KRC2005, No. 6E. Available online: http://www.iges.or.jp

[26] Rao, P., (2002) "Greening the supply chain: a new initiative in Sout East Asia”, International Journal of Operations and Production Management, Vol. 22, No. 6, pp 632-655.

[27] Zhu, Q., Geng, Y., Sarkis, J., \& Lai, K.H., (2011) "Evaluating Green Supply Chain Management among Chinese Manufacturers from the Ecological Modernization Perspective", Transportation Research Part E, 47, pp 808-821.

[28] Liu, X., Yang, J., Qu, S., Wang, L., Shishime, T., \& Bao, C., (2011) "Sustainable Production: Practices and Determinant Factors of Green Supply Chain Management of Chinese Companies", Business Strategy and the Environment.

[29] Li, Y., (2011) "Research on the Performance Measurement of Green Supply Chain Management in China”, Journal of Sustainable Development, Vol. 4, No. 3, pp 101-107.

[30a] Zhu, Q., Sarkis, J. \& Lai, K., (2008) "Green supply chain management implications for "closing the loop", Transportation Research Part E: Logistics and Transportation Review, Vol. 44, No. 1 , pp 1-18.

[30b] Zhu, Q., Sarkis, J., Cordeiro, J.J. \& Lai, K., (2008) "Firm-level correlates of emergent green supply chain management practices in the Chinese context", Omega, 36, pp 577-591.

[31] Zhu, Q., Sarkis, J., \& Geng, Y., (2005) "Green supply chain management in China: pressures, practices and performance", International Journal of Operations and Production Management, 25, pp 449-468.

[32] Diabat, A. \& Govindan, K., (2011) "An Analysis of the Drivers Affecting the Implementation of Green Supply Chain Management”, Resources, Conservation and Recycling. 55, pp 659-667.

[33] Eltayeb, T. K. \& Zailani, S.H.M., (2011) "Greening Supply Chain through Supply Chain Initiatives towards Environmental Sustainbility". 
International Journal of Managing Value and Supply Chains (IJMVSC) Vol. 3, No. 1, March 2012

[34] Eltayeb, T. K., Zailani, S. \& Ramayah, T., (2011) "Green supply chain initiatives among certified companies in Malaysia and environmental sustainability: Investigating the outcomes", Resource, Conservation and Recycling, 55, pp 495-506.

[35] Eltayeb, T. K. \& Zailani, S., (2009) "Going green through green supply chain initiatives towards environmental sustainability", Operations and Supply Chain Management, Vol. 2, No. 2, pp 93110 .

[36] Christmann P, Taylor G., (2001) "Globalization and the environment: determinants of firm selfregulation in China”, Journal of International Business Studies, Vol. 32, No. 3, pp 439-58.

[37] Wooi, G. C. \& Zailani, S., (2010) "Green supply chain initiatives: Investigating on the barriers in the context of SMEs in Malaysia", International Business Management, Vol. 4, No. 1, pp 20-27.

[38] Darnall, N., Jolley, G.J. \& Handfield, R., (2006) "Environmental management systems and green supply chain management: complements for sustainability?", Business Strategy and the Environment, article in press, DOI: 10.1002/bse.557. 